\title{
Older adults in the digital age in Latin America: bridging the digital age divide ${ }^{1}$
}

\author{
Guillermo Sunkel and Heidi Ullmann
}

\begin{abstract}
In recent decades, countries across Latin America have entered a stage of sustained population ageing. In parallel, changes associated with the rise of the digital society have profoundly transformed the way in which people in the region interact with each other and with their governments. This paper examines the use and appropriation of digital technologies among older adults in the region. In particular, it describes the evolution of Internet use by older adults in the region, using data from national household surveys; examines the determinants of Internet use among older adults, considering variables such as sex, ethnicity, education level and rural/urban residence using logistic regression analysis; and, lastly, highlights policies and programmes that are being implemented to promote the inclusion of older adults through the use of digital technologies.
\end{abstract}

\section{Keywords}

Ageing, Ageing persons, Internet, information technology, communication technology, digital divide, computer literacy, household surveys, programmes of action, ICT indicators, Latin America

\section{JEL classification}

I31, 035, J14

\section{Authors}

Guillermo Sunkel is a Social Affairs Officer in the Social Development Division of the Economic Commission for Latin America and the Caribbean (ECLAC) and holds a doctorate in cultural studies from the University of Birmingham. Email: guillermo.sunkel@cepal.org. Heidi Ullmann is a Social Affairs Officer in the Social Development Division of the Economic Commission for Latin America and the Caribbean (ECLAC) and holds a doctorate in public affairs from Princeton University. Email: heidi.ullmann@cepal.org.

The authors wish to acknowledge the contributions of Leydi Hernández, who completed an internship at the Economic Commission for Latin America and the Caribbean (ECLAC) in 2015 under the supervision of Guillermo Sunkel. This article draws heavily on the work Ms. Hernández did at ECLAC. The authors would also like to acknowledge Raymundo Mogollón for his support with data processing. 


\section{Introduction}

In recent decades, countries across Latin America have entered a stage of sustained population ageing. Pronounced declines in fertility rates accompanied by improvements in life expectancy have significantly modified the population age structure with a significant increase in the proportion of older adults. ${ }^{2}$ The United Nations estimates that by 2050, older adults will represent approximately one quarter of the whole population in the region (see figure 1). In accordance with the definition set forth in the Inter-American Convention on Protecting the Human Rights of Older Persons (OAS, 2015), for the purposes of this study, we define the older adult population as persons 60 years of age or over.

Figure 1

Latin America and the Caribbean: Population by age groups over time, 1985-2060 (Millions)

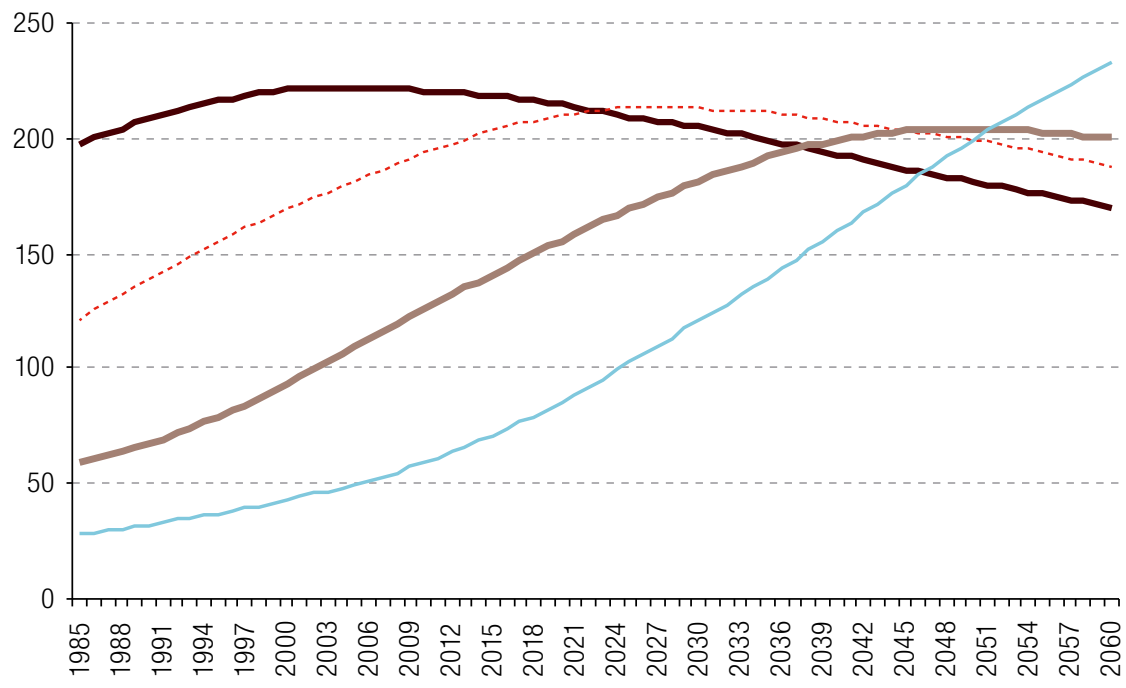

- 0-19 …20-39 $\quad$ 20-59 - 40+

Source: Prepared by the authors, on the basis of United Nations, World Population Prospects. The 2015 Revision (ESA/P/WP.241), New York, 2015.

However, there is some regional heterogeneity in this trend, as the ageing process has not been equally intense everywhere in the region. Table 1 depicts four country groups. The first group (seven countries) has relatively high levels of fertility (more than 3.3 children per woman) and an ageing index of less than 17 older adults for every 100 children under 15 years of age. These countries are in what ECLAC has termed the incipient stage of the demographic transition process. The second group consists of 15 countries with lower fertility rates (between 2.3 and 3 children per woman) and ageing indices that range between 19.8 and 31.9 , which means they are at the moderate stage of the ageing process. The three countries in the third group are at a moderate-to-advanced stage of ageing, as their fertility rates vary between 1.7 and 2.5 children per woman and their ageing indices range from 32.8 to 51 older adults per 100 children under the age of 15 (five countries). The fourth and final group (three countries) is in the advanced stage of ageing, with lower levels of fertility (below the replacement rate) and ageing indices over 65 (ECLAC, 2007).

\footnotetext{
2 The World Health Organization (WHO) defines older adults as all persons aged 60 years or over in developing countries and, in developed countries, all persons aged 65 years old or over, taking into consideration life expectancy at birth, among other factors. However, each country is free to establish the age at which its population is considered older adult. This is the case with Costa Rica and Uruguay, which set 65 as the age at which a person starts to be considered an older adult.
} 
Table 1

Latin America and the Caribbean: countries, by stage of population ageing process

\begin{tabular}{|c|c|c|}
\hline Stage & Description & Countries \\
\hline $\begin{array}{l}\text { Incipient } \\
\text { ageing }\end{array}$ & $\begin{array}{l}\text { Countries that have relatively high levels of fertility (over } \\
3.3 \text { children per woman) and an ageing index of less than } \\
17 \text { older adults for every } 100 \text { children under the age of } 15\end{array}$ & $\begin{array}{l}\text { Belize, Bolivia (Plurinational State of), Guatemala, Haiti, } \\
\text { Honduras, Nicaragua, Paraguay }\end{array}$ \\
\hline $\begin{array}{l}\text { Moderate } \\
\text { ageing }\end{array}$ & $\begin{array}{l}\text { Countries with lower fertility rates (between } 2.3 \text { and } \\
3 \text { children per woman) and ageing indices that range } \\
\text { between } 19.8 \text { and } 31.9\end{array}$ & $\begin{array}{l}\text { Bahamas, Brazil, Colombia, Costa Rica, Ecuador, El Salvador, } \\
\text { Guyana, Jamaica, Mexico, Panama, Peru, Dominican Republic, } \\
\text { Saint Lucia, Suriname and Venezuela (Bolivarian Republic of) }\end{array}$ \\
\hline $\begin{array}{l}\text { Moderate- } \\
\text { to-advanced } \\
\text { ageing }\end{array}$ & $\begin{array}{l}\text { Countries with fertility rates varying between } 1.7 \text { and } \\
2.5 \text { children per woman and ageing indices ranging from } \\
32.8 \text { to } 51 \text { older adults per } 100 \text { children under the age of } 15\end{array}$ & Argentina, Chile, Trinidad and Tobago \\
\hline $\begin{array}{l}\text { Advanced } \\
\text { ageing }\end{array}$ & $\begin{array}{l}\text { Countries have lower levels of fertility (below the replacement } \\
\text { rate) and ageing indices over } 65\end{array}$ & Barbados, Cuba, Uruguay \\
\hline
\end{tabular}

Source: Economic Commission for Latin America and the Caribbean (ECLAC), Report on the Application of the Regional Strategy for the Implementation in Latin America and the Caribbean of the Madrid International Plan of Action on Ageing (LC/L.2749(CRE.2/3)), Santiago, 2007.

Despite the fact that the ageing process has not been equally intense, the trend will soon affect all countries in the region. The increase in the older adult population will also prompt proportional increases in the specific social, economic, political and cultural demands of this population, which must be addressed and resolved through public policies in order to ensure their social inclusion, quality of life and the protection and promotion of their rights (ECLAC, 2016a; Huenchuan, 2013). As policymakers seek to guarantee greater autonomy and social integration of older adults, they are increasingly looking to the creation and implementation of digital inclusion initiatives for older persons, with the aim of empowering them in the use and appropriation of information and communications technology (ICT) for their daily activities.

It is well known that the changes associated with the rise of the digital and information society have profoundly transformed the way in which people in the region interact with each other and with their governments. As ECLAC notes (ECLAC, 2016b), between 2003 and 2015 -just a little over a decade - the number of Internet users more than doubled to comprise $54.4 \%$ of the population. Mirroring global trends, Internet penetration (measured as the percentage of the total population that has Internet access) more than doubled in Latin America and the Caribbean, from $20.7 \%$ to $54.4 \%$ between 2006 and 2015. However, the latter figure remained well below the $79.6 \%$ average posted by the countries of the Organization for Economic Cooperation and Development (OECD).

Indeed, the diffusion of ICT may have several implications, not only in the economic field but also in the social and political ones. In this regard, the World Summit on the Information Society (WSIS) has sought "to achieve a common vision, desire and commitment to build a people-centric, inclusive and development-oriented Information Society where everyone can create, access, utilize and share information" (WSIS, 2016). Since the first Summit in Geneva in 2003, ICT has been highlighted as a key development tool, with direct impacts on education, health and government services as well as on strengthening democracy, reducing poverty and promoting innovation and economic growth (Balboni, Rovira and Vergara, 2011).

Nevertheless, it is increasingly clear that access to digital media is not evenly distributed within and between countries, which leads to the conclusion that potential benefits are not equally distributed among different populations. Indeed, potential impacts of the media are neither automatic nor extended to all individuals. This uneven access, as well as other economic and social differences, can be worsened if there are no adequate policies to guarantee digital access and benefits to all sectors of society (Balboni, Rovira and Vergara, 2011). Building on this perspective, this paper argues that ICT not only has great potential for reducing social and economic inequalities that affect older adults, but can also exacerbate pre-existing economic or social inequalities or even create new ones. Thus, in relation to the subject under discussion, public policies must promote the positive role of new technologies for what they are: 
tools that can potentially create opportunities for promoting the inclusion of older adults in all spheres of daily life. Thus, digital inclusion is considered a way to promote social inclusion (Andreasson, 2015).

This work stresses the importance of integrating older persons in the digital world because, among other reasons, in the coming years they will represent a large proportion of the population. The main objective is to explore the use of digital media - particularly the Internet - among older adults in the region and to reflect on how those media can contribute to greater inclusion and better quality of life of this population. The paper seeks to examine whether (and to what extent) older persons are taking advantage of these opportunities. To this end, the following questions will be addressed:

What are the patterns of ICT use among older adults? Have these patterns of use changed over time? What individual-level characteristics are associated with ICT usage in the older adult population?

To answer these questions, this paper draws on data from national household surveys from eight countries in the region (Chile, Ecuador, El Salvador, Honduras, Mexico, Paraguay, Peru and Uruguay). ${ }^{3}$ The countries considered are those that have a recently-conducted household survey that includes an ICT module. ${ }^{4}$ In all cases, the surveys are nationally representative. Those countries with two recent waves that contain modules on ICT usage are used to examine the changes in ICT use among older adults. In order to make comparisons across surveys, the relevant variables were standardized. ${ }^{5}$ The analytic strategy involved multivariate logistic regression analysis to identify the individual-level characteristics that are associated with ICT usage among older adults in the region.

The article is divided into six sections including this introduction. Section II compares Internet access between older adults and other age groups and discusses the notion of an age-related digital divide. Section III describes patterns and trends of ICT use by older adults in the region, using data from national household surveys from seven countries in the region. Section IV identifies the determinants of these types of Internet use among the older adult population, considering variables such as sex, ethnicity (belonging to an indigenous group), education level and rural/urban residence. Section V highlights policies and programmes that are being implemented to promote the inclusion of older adults through the use of ICT. Lastly, section VI draws conclusions and provides some recommendations for furthering the use of ICT in the older adult population.

\section{The digital age divide}

Historically, older adults have been considered to be persons whose capacities for carrying out productive activities related to the economic process are diminished. The tendency to undervalue the experience and knowledge of older persons has meant that they have come to be regarded as passive persons in the process of development of societies (Abusleme and others, 2014) and, therefore, as on the fringes of social progress.

\footnotetext{
3 These surveys are: the National Socioeconomic Survey (CASEN) of Chile, 2015; the National Survey of Employment, Unemployment and Underemployment in urban and rural areas of Ecuador, 2015; the Multi-purpose Household Survey of El Salvador, 2015; the Permanent Multi-purpose Household Survey of Honduras, 2014; the Module on Availability and Use of Information Technologies in Households (MODUTIH) of Mexico, 2014; the Permanent Household Survey of Paraguay, 2015; the National Household Survey on Life Conditions and Poverty of Peru, 2015; and the Continuous Household Survey of Uruguay, 2015.

4 Most household surveys from countries in the region contain household-level information on ICT availability, typically: whether the household has a cellular phone, a computer and an Internet connection. The eight surveys used in this analysis contain individual-level ICT usage information, which is deemed to be superior to household-level information, since general access to ICT for the household does not guarantee its use among all household members. The individual-level ICT modules contain questions about each household member's use of: cellular phones, computer, the Internet, as well as frequency and place of use. Given the growing interest in ICT usage among persons in the region, standardized modules have been developed and incorporated, which facilitates comparisons across surveys.

5 For sample characteristics, please see annex A1.
} 
At present, public policy seeks to modify this notion of older persons through campaigns that promote the culture of "active ageing", defined as "the process of optimizing opportunities for health, participation and security in order to enhance quality of life as people age". It applies to both individuals and population groups and allows people to realize their potential for physical, social and mental well-being throughout the life course and to participate in society, while providing them with adequate protection, security and care when they require assistance (WHO, 2002). Undoubtedly, promoting access to and use of digital media amongst older adults is invaluable for advancing the culture of active ageing.

However, one of the social effects of digital technologies in the modern world is that they have become a "new" factor that distinguishes older adults from younger population groups. Indeed, available ICT statistics for Latin America show that the older adult age group is the most isolated from digital technologies, reflecting a deep digital age divide.

The digital divide is a dichotomous concept that was first used in the 1990s to refer to the gap that was developing between countries, social groups and/or persons that had access to digital technologies and those that did not (Selwyn, 2004; Selwyn and Facer, 2007). The concept is particularly relevant when it refers to the reality of developing countries with an ageing population and where digital technologies can have a profound impact on the lives of older adults.

Prensky (2001) has argued that it is important to distinguish between digital natives and digital immigrants. He holds that the former - children and youth who were born and have grown up in the digital age - are characterized by a continuous and prolonged exposure to digital media and by the degree to which they (naturally) integrate them to their daily activities. The latter - "digital immigrants" - are those who were not born in the digital world and have had to adapt to the new environment (Prensky, 2001). This category includes older persons who come from a different cultural "environment" and have had to deal with technological innovations to try to adopt them in their daily lives (Piscitelli, 2009).

There is ample evidence of a digital divide between adults aged 60 and over and other population age groups in Latin America. Figure 2 shows that there is a lower level of Internet use among older persons than young people and adults in all the countries for which data are available and the gaps are quite striking. For example, reported Internet use among people aged 15-29 was more than seven times that of older adults in El Salvador and Honduras; that figure was eight times higher in Mexico and almost nine times higher in Ecuador. ${ }^{6}$

Patterns of use and access locations also differ across these population subgroups. Table 2 shows the most common locations of Internet access among the 15-29, 30-59 and 60 and over age groups in six countries. Clear differences are noted between the age groups. Most notably, as age increases, the percentage of users who access the Internet at home rises, while higher percentages of young people access the Internet from public locations and schools or other educational facilities.

The results of the analysis of the digital divide in the region show that, compared to other population age groups, older adults use the Internet the least, but they are the ones who access it most from the home. This trend may be attributable to mobility limitations or health problems that constrain their ability to leave the home. Alternatively, some older adults may choose not to leave their home. In contrast, the figures show that younger people rely primarily on Internet access outside of the home. While the data did not allow direct measurement of Internet access via mobile devices outside of the home, it is possible that an even larger proportion of young people access the Internet in this way.

\footnotetext{
6 Disaggregated data for older adults aged 60-74 and adults aged 75 and over would have shed further light on the differences in Internet usage, but due to sample size limitations, this was not possible.
} 
Figure 2

Latin America (selected countries): individuals using the Internet, by age group, around $2015^{\mathrm{a}}$ (Percentages)

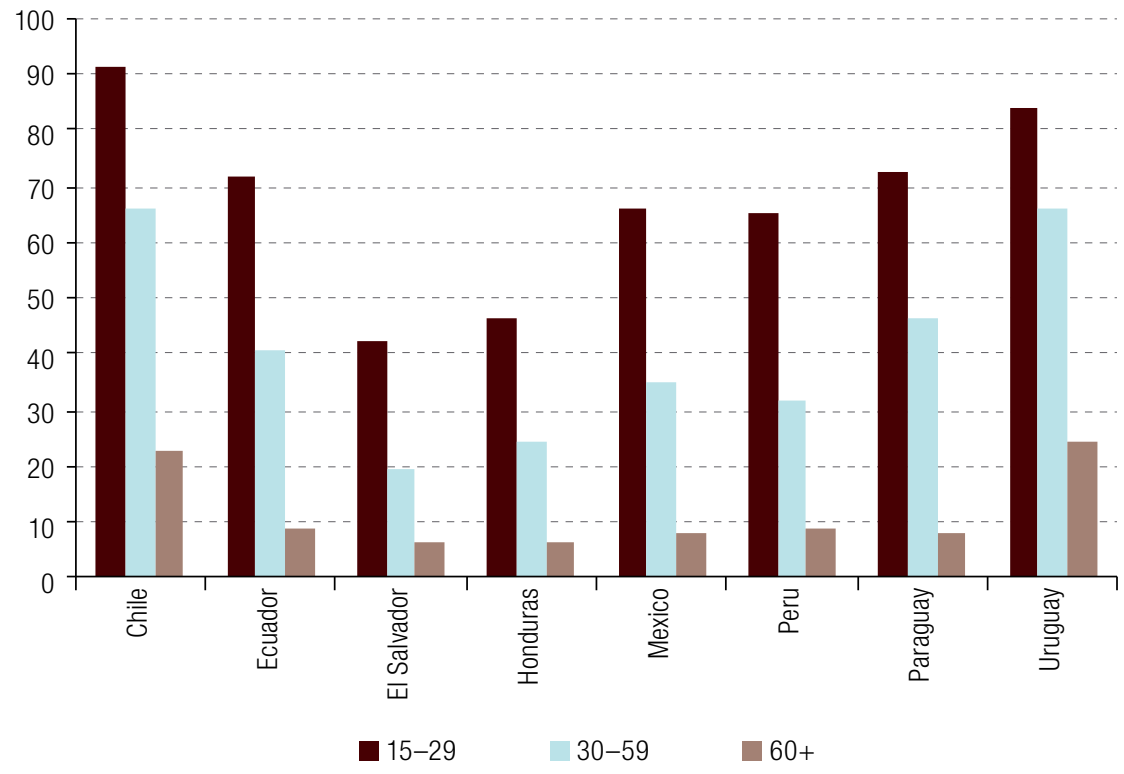

Source: Prepared by the authors, on the basis of data from national surveys.

a Surveys were conducted in 2015, except in Honduras and Mexico, where they were conducted in 2014.

Table 2

Latin America (selected countries): Internet use, by location of access and age group, around $2015^{\mathrm{a}}$

(Percentages)

\begin{tabular}{|c|c|c|c|c|c|}
\hline Country & Age & Home & Workplace & School & Public place \\
\hline & $15-29$ & 76.6 & 6.1 & 6.8 & 0.3 \\
\hline \multirow[t]{3}{*}{ Chile } & $30-59$ & 77.0 & 15.3 & 0.1 & 0.2 \\
\hline & $60+$ & 86.6 & 9.5 & 0.0 & 0.2 \\
\hline & $15-29$ & 52.8 & 12.5 & 23.7 & 48.1 \\
\hline \multirow[t]{3}{*}{ Ecuador } & $30-59$ & 73.4 & 34.8 & 2.5 & 23.0 \\
\hline & $60+$ & 89.0 & 27.7 & 1.6 & 8.4 \\
\hline & 15-29 & 33.5 & 2.2 & 5.7 & 0.1 \\
\hline \multirow[t]{3}{*}{ El Salvador } & $30-59$ & 53.8 & 10.0 & 0.3 & 0.0 \\
\hline & $60+$ & 83.7 & 5.5 & 0.4 & 0.0 \\
\hline & $15-29$ & 33.1 & 8.6 & 16.4 & \\
\hline \multirow[t]{3}{*}{ Honduras } & $30-59$ & 43.8 & 25.7 & 2.6 & \\
\hline & $60+$ & 67.4 & 15.2 & 0.6 & \\
\hline & $15-29$ & 48.9 & 8.1 & 7.9 & 31.5 \\
\hline \multirow[t]{3}{*}{ Mexico } & $30-59$ & 63.0 & 20.3 & 0.0 & 13.3 \\
\hline & $60+$ & 79.5 & 12.5 & 0.3 & 5.5 \\
\hline & $15-29$ & 33.7 & 9.1 & 8.5 & \\
\hline \multirow[t]{2}{*}{ Peru } & $30-59$ & 53.1 & 27.3 & 0.9 & \\
\hline & $60+$ & 75.4 & 23.6 & 0.7 & \\
\hline
\end{tabular}

Source: Prepared by the authors, on the basis of data from national surveys.

a Surveys were conducted in 2015, except in Mexico, where they were conducted in 2014. 


\section{Patterns of ICT use by older persons in Latin America}

This paper seeks to examine whether (and to what extent) older persons are taking advantage of opportunities in information and communications technology. To this end, it considers the patterns of ICT use among older adults and whether these patterns have changed over time, as well as the individual-level characteristics associated with ICT use in the older adult population. The aim is to provide a rich statistical portrait of ICT use by older persons and thereby offer evidence and recommendations that can help to guide policies that better incorporate older adults into the digital society.

The data on older adults' access to a computer show substantial variations between the countries studied (figure 3). While $45.7 \%$ of older adults in Uruguay live in a household with a computer, the number falls to $16.6 \%$ in Honduras. This diversity is not surprising, in view of the considerable gaps in economic and social development within the region. What is also clear from figure 3 is that household access to a computer does not equate with computer use by older adults. In five of the seven countries for which both indicators are available (Ecuador, El Salvador, Mexico, Paraguay and Peru), the proportion of this population using computers is lower than the proportion that has a computer in the home. Thus, there is a segment of the older adult population that has theoretical access to computers but does not use them.

Figure 3

Latin America (selected countries): adults aged 60 or over living in households with computers and using computers, around $2015^{\mathrm{a}}$

(Percentages)

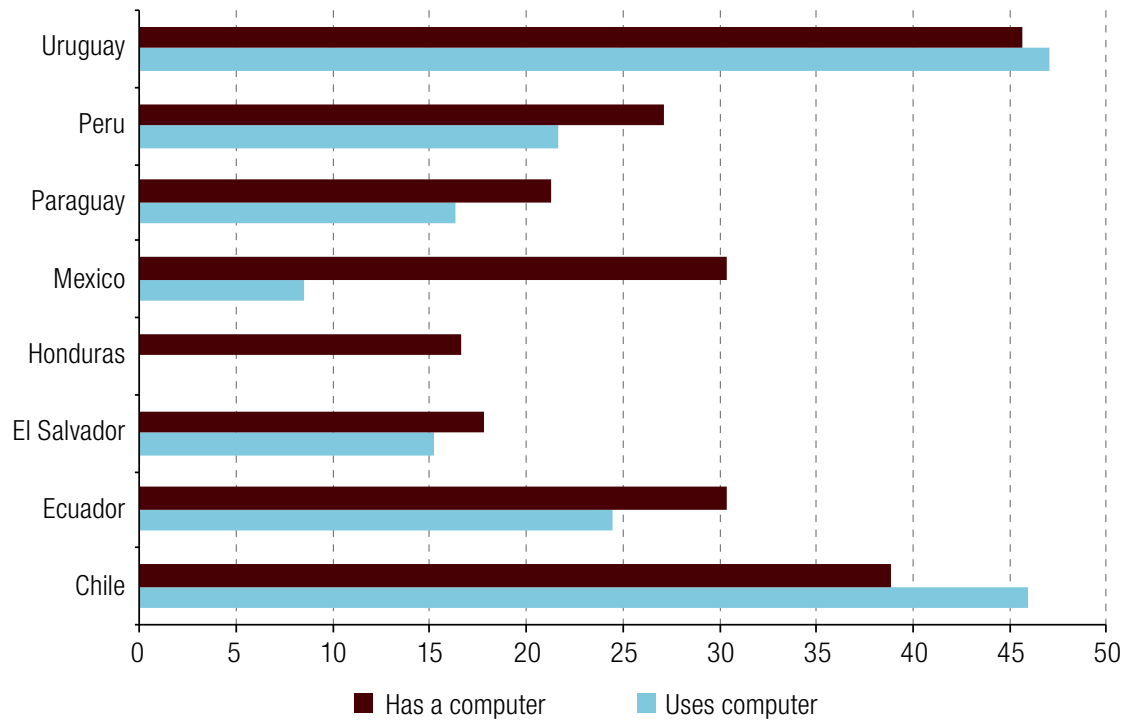

Source: Prepared by the authors, on the basis of data from national surveys.

a Surveys were conducted in 2015, except in Mexico, where they were conducted in 2014.

Correspondingly, the percentage of older adults using the Internet is also low (figure 4), ranging from $24.5 \%$ in Uruguay to $6.1 \%$ in Honduras. This variation not only reflects the uneven educational levels of the populations in each of the countries, but also, more generally, the levels of economic and social development and broadband and Internet connectivity.

The data therefore suggest that older adults are not active participants in the digital societies in which they reside and that there is significant room to expand Internet usage among older adults in the region. Selwyn (2003) argues that the access to and use of digital media is dependent on the 
particular characteristics of the individual. The author discusses various factors that can influence non-users (or "offliners") in their decision not to use digital media. These include: discourses of material and cognitive deficiency, technophobia, ideological refusal and diffusion theory.

Figure 4

Latin America (selected countries): adults aged 60 or over using the Internet, around $2015^{\mathrm{a}}$ (Percentages)

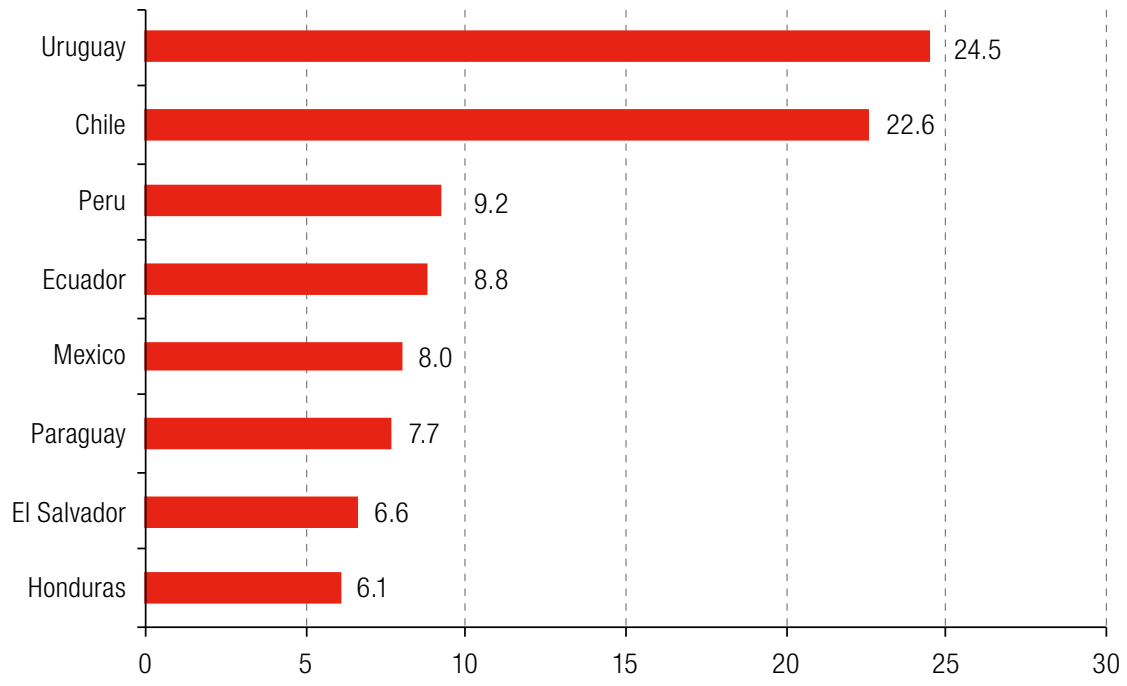

Source: Prepared by the authors, on the basis of data from national surveys.

a Surveys were conducted in 2015, except in Mexico, where they were conducted in 2014.

With regard to the first factor, he posits that discourses of material restrictions are related to economic and material resources. For some people - particularly those in less favourable conditionsthe cost of a digital device might determine the quality of the device purchased or whether a device is even purchased at all. However, access to digital media is irrelevant if there are limitations regarding their use. The author states that discourses of cognitive deficiency are related to intellectual capabilities and to technological skills and that attitudes towards new technology become more positive as individuals gain more experience in using them (Selwyn, 2003).

On the second factor - technophobia, understood as an individual's fear (and apprehension) of technology, particularly the consequences of its use- Selwyn notes a significant correlation with individual characteristics such as gender and age. However, the feeling of anxiety commonly produced by technophobia may disappear as interaction with technology increases. In this regard, Van Deursen and Van Dijk (2014) state that motivation, access, skills and the use of digital media may be influenced by personal characteristics. It is for this reason that technology developers try to create user-friendly technology, that is, hardware and software specially designed for easy use. The third factor, ideological refusal, reflects an individual choice of those persons who do not want to relate to technology even though they are in a position to do so. Lastly, Selwyn (2003) argues that diffusion theory can explain the reluctance of non-use to purchase and adopt a technology that will be quickly replaced by a newer one on the market.

Following this line of thought, Castaño (2008) argues that although the digital divide may seem to be technological in character, it is, rather, a social one. This is because the digital divide - understood as the unequal access to and use of Internet amongst generations (Boonaert and Vettenburg (2011) quoted in Elwick and others, 2013) - is interconnected with other factors that influence s ocial exclusion, such as economic resources, availability of time, knowledge, skills, and cultural and linguistic background. The digital divide may be explained by the different interests, needs, experiences, attitudes and values 
of each age group. The perception of the usefulness of a technology for a given activity will condition the degree of interaction an individual has with technology, including the reluctance to use it. In this sense, the extent of Internet use will depend on how, by whom and why it is used (Camacho, 2004).

In line with Murdock's model, cited in Selwyn, 2003, and on the basis of the available data, young people and adults can be classified in general terms as "core users", while older persons can be classified as either "peripheral users" or "excluded users" of the Internet for the purposes of searching for information, communication and the production of materials (table 3).

Table 3

Types of ICT users

"Core" users Continuous and comprehensive use of ICT for information seeking, communication and creation/production of materials

"Peripheral" users Sporadic and limited use of ICT for information seeking, communication and creation/production of materials

"Excluded" users Non-existent use of ICT for information seeking, communication and creation/production of materials

Source: Prepared by the authors, on the basis of N. Selwyn, "Apart from technology: understanding people's non-use of information and communication technologies in everyday life", Technology in Society, vol. 25, No. 1, Amsterdam, Elsevier, 2003.

The different degrees of interaction with ICT are related to what Castaño (2008) has termed the "second digital divide", which affects the type of use (in terms of intensity and variety) and is determined by people's computer and Internet access and skills. In this regard, Van Deursen and Van Dijk (2014) argue that digital skills are the "key to the entire process of the appropriation of these new technologies" and that continuous effort and motivation are required to develop those skills.

\section{Evolution of ICT usage among older adults}

Despite the generally low access to computers and Internet usage among older adults in the region documented above, it must be noted that there has been an important increase in ICT usage among this population in the past five years, which occurred in a larger context of Internet and ICT penetration in the region (ECLAC, 2016b). In terms of household-level access to a computer (figure 5), the expansion was greatest in Uruguay, where just under $19 \%$ of older adults lived in a household with a computer in 2008 , compared to over $45 \%$ in 2015 , a more than two-fold increase in just seven years.

Figure 5

Latin America (selected countries): adults aged 60 or over living in households with computers, 2008 and 2015

(Percentages)

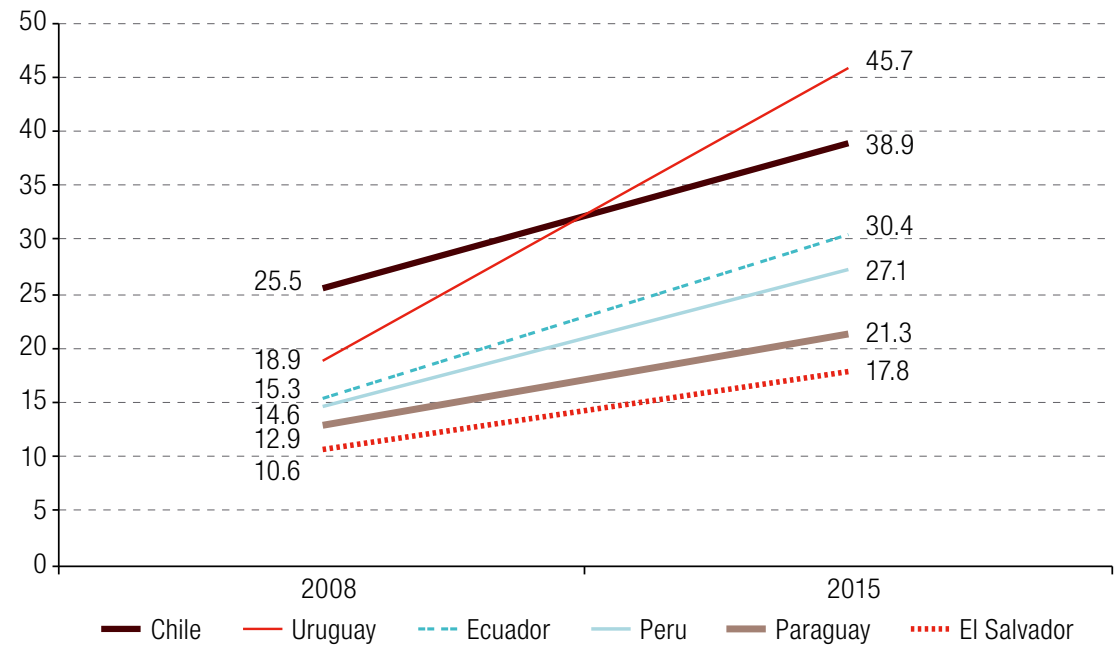

Source: Prepared by the authors, on the basis of data from national surveys. 
The data show corresponding increases for Internet use among older adults (figure 6), although these levels are still quite low in some countries, with under $10 \%$ of older adults in three of the five countries examined responding that they use the Internet.

Figure 6

Latin America (selected countries): adults aged 60 or over using the Internet, 2008 and 2015

(Percentages)

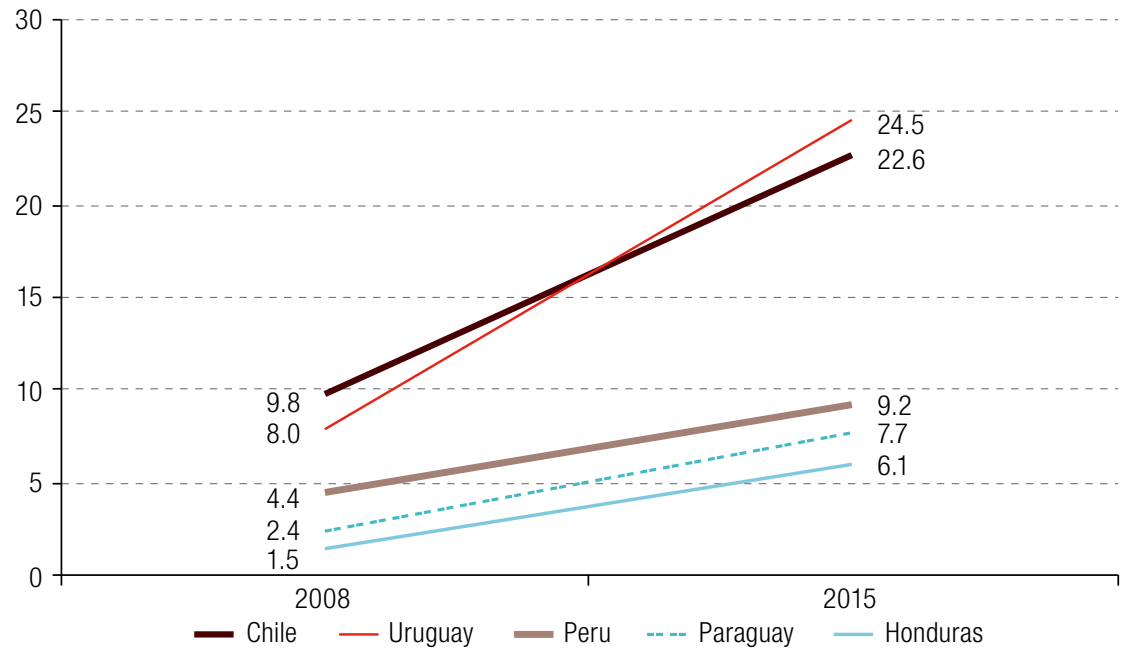

Source: Prepared by the authors, on the basis of data from national surveys.

\section{Characteristics of Internet use by older adults}

Although, in general, only a small percentage of older adults in Latin America use the Internet, those who do are frequent users, with a majority of them going online every day (figure 7). This suggests that the Internet serves a daily purpose for those older adults who have adopted it. The high level of Internet access and use in a segment of the older adult population in Latin America suggests that they are "core users", as per the classification presented in table 3. Nonetheless, these data do not indicate how much of their Internet usage is dedicated to searching for information, communicating or producing content.

Figure 7

Latin America (selected countries): frequency of Internet use by adults aged 60 or over, around 2015ª (Percentages)

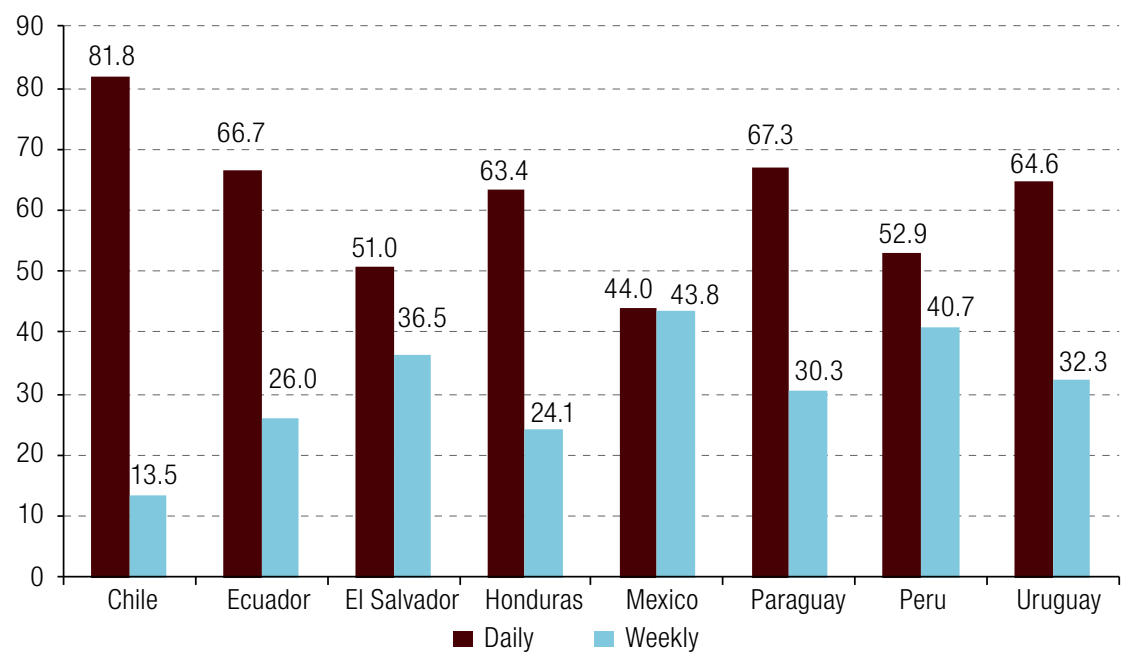

Source: Prepared by the authors, on the basis of data from national surveys.

a Surveys were conducted in 2015, except in Mexico, where they were conducted in 2014. 
To ascertain the main online activities of older adults in the region, this article examines the activities included in the household surveys, namely: information seeking, communication (including email and chatting), education (and training), entertainment, online banking, shopping and carrying out administrative tasks. Despite the above-mentioned heterogeneity in Internet use among older adults in the countries under analysis, the types of activities are somewhat consistent across countries. The Internet is primarily used to search for information and for communication (figure 8).

Figure 8

Latin America (selected countries): adults aged 60 or over using the Internet, by type of activity, around $2015^{\mathrm{a}}$

(Percentages)

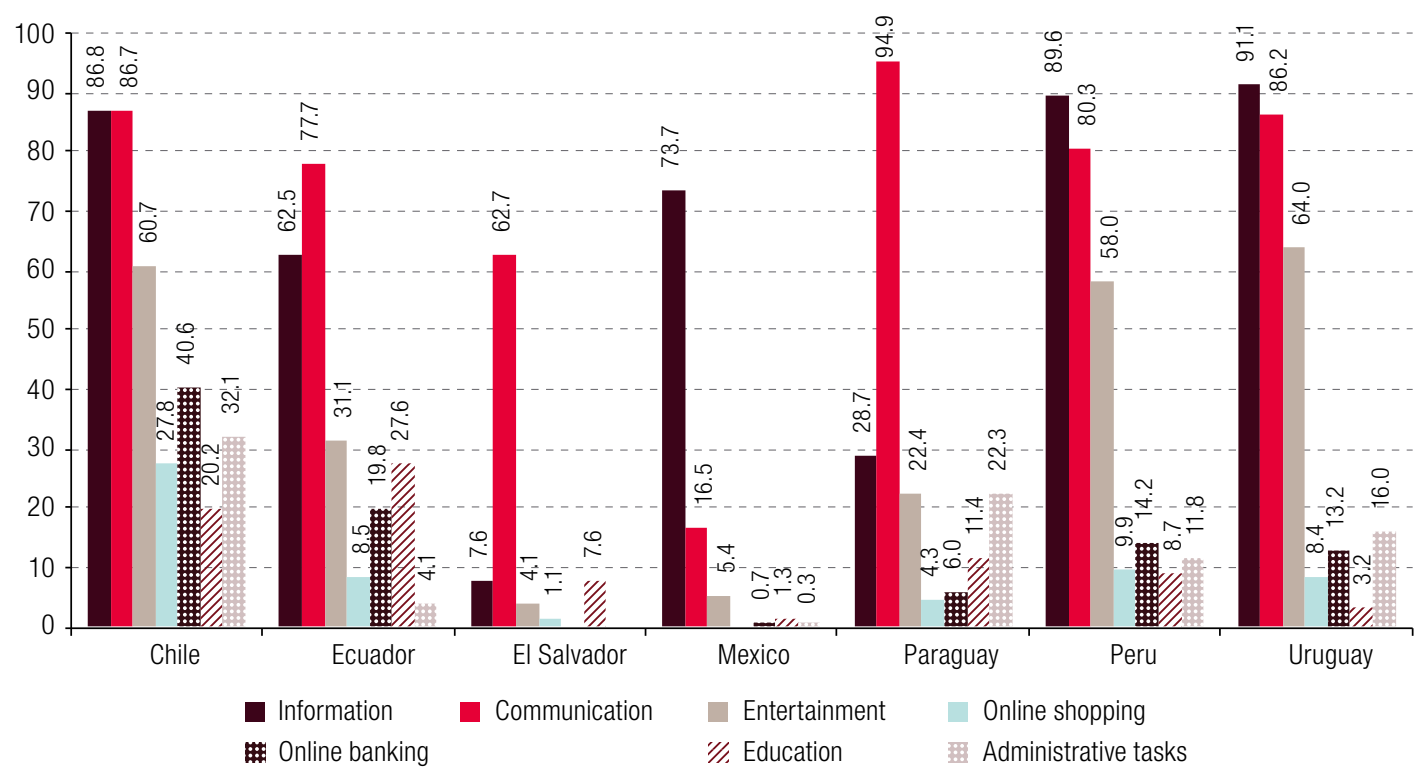

Source: Prepared by the authors, on the basis of data from national surveys.

a Data for Mexico taken from Module on Availability and Use of Information Technologies in Households (MODUTIH), 2010.

Among older adults, use of the Internet for communication is especially important. Videotelephony software such as Skype or FaceTime make it possible to hold virtual meetings with persons in any location, providing, along with other communication tools, an avenue for older adults to stay in touch with family and friends in an age when it is common for families to live far apart. Moreover, online communication tools allow older adults with limited mobility or hearing to maintain social and interpersonal bonds without having to leave the home. While one might reasonably expect mobility and/or communication difficulties to render other transactions such as Internet shopping or banking more common among older adults, these registered low levels in most of the countries considered.

The fear of using technology (owing to a perceived lack of mastery) together with the security threats and distrust associated with conducting financial transactions on digital devices are possible factors that contribute to older adults' reluctance to use electronic banking or to purchase online. Moreover, in Latin American societies, trips to the bank or shops may represent opportunities for interaction and socialization with others and, in that regard, may be valued by older adults, even those with mobility or communication limitations.

The data also show that a high percentage of users connect to the Internet for entertainment activities, such as viewing and downloading videos, music and movies. In Chile, $60.7 \%$ of older adults report using the Internet for entertainment, while that figure stands at $64 \%$ in Uruguay. Digital media are not only a pastime for older adults, but can also be a means of combating loneliness. Nonetheless, traditional forms of entertainment and social interaction remain firmly rooted among older persons in these societies. 
Lastly, it is interesting to note that in countries such as Chile and Uruguay where Internet usage is more widespread in general, older adults seem to engage in a wider set of online activities, particularly for the administrative procedures of public institutions.

\section{Determinants of Internet use among older adults}

In this section, multivariate logistic regression models are used to identify predictors of computer ownership and Internet use. This highlights the sociodemographic factors associated with these two indicators, which can help to pinpoint particular social groups that could benefit from targeted action to expand access to ICT.

The odds ratios from multivariate logistic regression analyses to identify predictors of computer ownership (table 4) and using the Internet (table 5) among older adults in the region are presented below. An odds ratio of 1 means that the variable does not affect the outcome -in this case, one of the two indicators of ICT usage. Values below 1 indicate lower odds of ICT use, whereas values above 1 indicate higher odds of ICT use.

Table 4

Latin America (selected countries): odds ratios from multivariate logistic regression analyses predicting computer ownership among adults aged 60 or older

\begin{tabular}{|c|c|c|c|c|c|c|c|}
\hline & Chile & Ecuador & El Salvador & Mexico & Paraguay & Peru & Uruguay \\
\hline Mean age & $0.98^{* *}$ & 1.00 & $1.01^{* \star *}$ & $1.01^{* *}$ & $1.01^{*}$ & 1.02 ** & $0.97^{\text {** }}$ \\
\hline Male & $0.42^{* *}$ & $0.83^{* *}$ & $0.75^{* *}$ & $0.83^{* *}$ & 1.00 & $0.73^{* *}$ & $1.12^{\text {** }}$ \\
\hline Urban & 1.30 ** & $2.95^{\text {** }}$ & 2.88 ** & $3.85^{* *}$ & $4.43^{\star \star}$ & $6.54^{* *}$ & 1.64 ** \\
\hline Years of education & 1.09 ** & 1.23 ** & $1.18^{\star \star}$ & $1.23^{* *}$ & $1.21^{\star \star}$ & $1.19^{\star *}$ & $1.25^{\text {** }}$ \\
\hline Indigenous ethnicity & $0.87^{* *}$ & $0.71^{* *}$ & 1.00 & $0.72^{* *}$ & 1.00 & $0.94^{* \star *}$ & 0.97 \\
\hline With children & 2.00 ** & $5.95^{\text {** }}$ & 3.17 ** & 3.56 ** & 5.27 ** & $5.84^{\star \star}$ & $5.95^{* *}$ \\
\hline
\end{tabular}

Source: Prepared by the authors, on the basis of data from national surveys.

Note: Results are statistically significant at the ${ }^{\star \star} 0.01,{ }^{\star} 0.05$, and ${ }^{\star \star \star} 0.10$ level.

Table 5

Latin America (selected countries): odds ratios from multivariate logistic regression analyses predicting Internet use among adults aged 60 or older

\begin{tabular}{|c|c|c|c|c|c|}
\hline & Chile & Ecuador & El Salvador & Peru & Uruguay \\
\hline Mean age & $0.93^{* *}$ & $0.91^{* *}$ & 0.96 ** & $0.92^{\star *}$ & $0.91^{* *}$ \\
\hline Male & $1.10^{* *}$ & $1.24^{\star *}$ & 1.09 & 1.32 ** & 1.00 \\
\hline Urban & $2.31^{\star *}$ & $2.23^{\star *}$ & 2.58 ** & 5.09 ** & 1.62 ** \\
\hline Mean years of education & 1.36 ** & $1.44^{* *}$ & 1.40 ** & $1.43^{* *}$ & $1.37^{\text {** }}$ \\
\hline Indigenous ethnicity & $0.80^{* \star}$ & 0.95 & 1.00 & $0.74^{\star *}$ & $0.81^{\text {** }}$ \\
\hline With children & $1.13^{* *}$ & $0.82 *$ & 0.93 & 0.99 & 0.81 ** \\
\hline
\end{tabular}

Source: Prepared by the authors, on the basis of data from national surveys.

Note: Results are statistically significant at the ${ }^{* \star} 0.01,{ }^{*} 0.05$, and ${ }^{* \star \star} 0.10$ level.

The results in table 4 indicate that in all of the seven countries, older adults living in urban areas have higher odds of owning a computer than those living in rural areas, ranging from 1.30 higher odds in Chile to 6.54 in Peru. Similarly, the likelihood of computer ownership is higher among older adults with higher levels of education and those who have had children. Lastly, older adults belonging to ethnic minorities have a lower likelihood of owning a computer. 
The relationship between computer ownership and the variables of age and sex is not consistent in the seven countries in table 4. In some countries, the odds of owning a computer are lower with each additional year of age, whereas in others they are higher. Patterns are also mixed when disaggregated by sex - while, in Uruguay, men are more likely than women to live in a household with a computer, in the other countries, they are less likely than women to live in a household that owns a computer.

The patterns are more consistent when Internet usage among older adults (table 5) is examined. As age increases, the odds of using the Internet decreases in the five countries examined. In three of the five countries (Chile, Ecuador and Peru), men are more likely than women to use the Internet. Older adults belonging to an ethnic minority have lower odds of using the Internet than older adults who do not belong to such groups in Chile, Peru and Uruguay. As with computer ownership, there is a statistically significant association between urban residence and Internet use among older adults in the region. Each additional year of education increases the odds of using the Internet. Lastly, having children in the household is associated with higher odds of using the Internet in one of the five countries (Chile), whereas this is associated with lower odds of using the Internet in Ecuador and Uruguay.

In sum, despite increases over the past few years, computer ownership and use and Internet usage remain low among older adults in the region. However, a majority of those older adults who do use the Internet have incorporated it into their daily routines, the main uses being searching for information and communication. The factors that are most consistently associated with computer ownership and Internet usage are urban residence and educational attainment. On the other hand, older adults belonging to an ethnic minority, in particular indigenous populations, are less likely to have access to a computer at home and to use the Internet.

The relationship between ICT usage in the region and education has been documented by other research (Gutiérrez and Gamboa, 2010) and can be explained in two ways. First, as educational attainment is a proxy for socioeconomic status, those with higher levels of education likely have higher socioeconomic status and are, therefore, more likely to have the financial resources to access ICT. It is also true that ICT usage requires a certain level of literacy and skills, so that those with higher levels of education are more able to engage in these activities.

The association between urban residence and ICT usage is feasibly related to the greater availability of technological goods and wider Internet connectivity in cities. In the four countries that measure ethnicity, adults belonging to ethnic minorities are systematically less likely to use the Internet. This is consistent with a generalized pattern of exclusion and marginalization of these groups that may also be related to linguistic and cultural issues.

One last finding is that, as age increases, the odds of Internet use declines - it is the younger older adults who have an advantage in Internet usage. The relationship between ICT usage (particularly having a computer) and having children suggests that younger generations are instrumental in introducing and exposing their parents to the potential uses of ICT. That said, there is clearly a wide margin for increasing ICT access and use for older adults in the region.

Although much has been written about the digital divide between generations, these results suggest that there is another digital divide: one within the older adult population. ICT penetration is heavily concentrated among specific groups of older adults: those who are educated, reside in urban areas, and do not belong to indigenous groups. Thus, the diffusion of technologies seems to replicate other socioeconomic inequalities. 


\section{Programmes that promote the digital inclusion of older adults}

To complement the picture drawn in the previous sections, it is important to examine what the different countries of the region are doing to bridge the digital age gap. Therefore, this section highlights some of the policies and programmes that are being implemented to promote the inclusion of older adults through the use of ICT. The aim is to provide an initial mapping of how the problem of the digital age divide is being addressed in the region. These experiences (or practices) have been identified through a web search for programmes targeting older adults implemented by various institutions in the different countries of the region.

It should be recognized that there are some regional instruments on the rights of older adults which enshrine the right to ICT access. ${ }^{7}$ For example, the San José Charter on the Rights of Older Persons in Latin America and the Caribbean, adopted by government representatives at the Third Regional Intergovernmental Conference on Ageing in Latin America and the Caribbean in 2012, specifically refers to the need to "promote actions to guarantee access by older persons to information and communication technologies, in order to reduce the technological divide" (ECLAC, 2012).

More recently, in 2015, the member States of the Organization of American States (OAS) adopted the Inter-American Convention on Protecting the Human Rights of Older Persons (OAS, 2015), which specifically mentions access to ICT in relation to the right to education and the right to accessibility and personal mobility. Under the Convention, the States Parties undertake to "promote education and training for older persons in the use of new information and communication technologies (ICTs) in order to bridge the digital, generational, and geographical divide and to increase social and community integration" (article 20 (d)) and to "promote access for older persons, at the lowest possible cost, to new information and communication technologies and systems, including the Internet" (article 26 (e)).

In addition to this normative framework, since the mid-2000s, Latin American and Caribbean countries have embraced the notion of ICT for development, adopting the Plan of Action for the Information Society in Latin America and the Caribbean (eLAC), which underlines the importance of information and communication technologies (ICT) as tools for economic development and social inclusion. In 2005, during the preparatory meetings for the second phase of WSIS, the countries of the region agreed on the Plan of Action eLAC 2007. Subsequent Plans, namely eLAC 2010, eLAC 2015 and, most recently, eLAC 2018 guarantee the continuity of this engagement.

In the Mexico City Declaration, the outcome of the fifth Ministerial Conference on the Information Society in Latin America and the Caribbean, the countries of the region renewed the agreements of the eLAC process through the and adopted the new digital agenda eLAC 2018, which sets out 23 policy objectives in five areas of action: (i) access and infrastructure; (ii) digital economy, innovation and competitiveness; (iii) e-government and citizenship; (iv) sustainable development and inclusion; and (v) governance for the information society. In order to advance towards the policy objectives laid out in the eLAC regional framework for ICT, many countries in the region have adopted digital agendas, many of which make specific mention of the inclusion of older adults (see table 6).

\footnotetext{
7 Countries of the region adhere to the Madrid International Plan of Action on Ageing (2002) which, in "Objective 1: Equality of opportunity throughout life with respect to continuing education, training and retraining as well as vocational guidance and placement services", calls on governments to "ensure that the benefits of new technologies, especially information and communication technologies, are available to all, taking into account the needs of older women" and, in Objective 2: Full utilization of the potential and expertise of persons of all ages, recognizing the benefits of increased experience with age, to "encourage older volunteers to offer their skills in all fields of activities, in particular information technologies" (United Nations, 2002).
} 
Table 6

Latin America (selected countries): national digital agendas and plans with specific mention of older adults

\begin{tabular}{|c|c|c|}
\hline Country & Agenda/Plan & Mentions of and references to older adults \\
\hline \multirow[t]{3}{*}{ Costa Rica } & \multirow[t]{3}{*}{$\begin{array}{l}\text { National Telecommunications } \\
\text { Development Plan 2015-2021 } \\
\text { "Costa Rica: Una } \\
\text { sociedad conectada" }\end{array}$} & $\begin{array}{l}\text { (Projects) should be inclusive, serving the general population, including vulnerable populations, } \\
\text { that is those who are economically disadvantaged, and with an emphasis on persons with } \\
\text { disabilities, children and young people, older adults, indigenous peoples, female heads of } \\
\text { households and microentrepreneurs, as well as the public institutions that attend to them. }\end{array}$ \\
\hline & & $\begin{array}{l}\text { All persons (including persons with disabilities) shall be guaranteed access to broadcasting } \\
\text { services of high technical quality, on equal terms and without discrimination. }\end{array}$ \\
\hline & & $\begin{array}{l}\text { In addition, the production of software and content and applications development shall promote } \\
\text { accessibility, with a view to offering innovative products and services. }\end{array}$ \\
\hline Guatemala & $\begin{array}{l}\text { National Agenda for the } \\
\text { Information and Knowledge } \\
\text { Society of Guatemala }\end{array}$ & $\begin{array}{l}\text { Implement an "education for life" system, with the participation of older adults and persons } \\
\text { with disabilities. }\end{array}$ \\
\hline \multirow[t]{3}{*}{ Honduras } & \multirow{3}{*}{$\begin{array}{l}\text { Digital Agenda of Honduras } \\
\text { 2014-2018: connectivity, } \\
\text { transparency, and efficiency }\end{array}$} & $\begin{array}{l}\text { Promote the digital inclusion of indigenous peoples and communities, persons with disabilities } \\
\text { and older adults. }\end{array}$ \\
\hline & & $\begin{array}{l}\text { Establish broadband internet access centres for rural and urban communities and accessible } \\
\text { to all users, and the installation of screen reader software for persons with visual disabilities. }\end{array}$ \\
\hline & & Promote the labour inclusion of persons with disabilities through teleworking. \\
\hline Mexico & $\begin{array}{l}\text { National Digital Strategy, } \\
\text { 2013-2018 }\end{array}$ & $\begin{array}{l}\text { Enhance the National Digital Inclusion Campaign with special emphasis on indigenous peoples, } \\
\text { older adults, persons with disabilities and groups that are marginalized and living } \\
\text { in extreme poverty. }\end{array}$ \\
\hline \multirow[t]{2}{*}{ Peru } & \multirow[t]{2}{*}{$\begin{array}{l}\text { Plan for the Development of } \\
\text { an Information and Knowledge } \\
\text { Society in Peru - the Peruvian } \\
\text { Digital Agenda } 2.0\end{array}$} & $\begin{array}{l}\text { The developments necessary to move towards the information and knowledge Society in Peru } \\
\text { must include actions that adequately address disability and diversity from the perspective } \\
\text { of equal rights and opportunities, non-discrimination, universal accessibility and the removal } \\
\text { of barriers for various vulnerable groups. }\end{array}$ \\
\hline & & $\begin{array}{l}\text { The foregoing is not limited to promoting policies to increase access to computers and the } \\
\text { Internet, and/or ensure that points of access such as public Internet kiosks and telecentres are } \\
\text { equipped to welcome different categories users, including persons with disabilities, older } \\
\text { persons, children, indigenous peoples and Afrodescendants, among others. It also implies } \\
\text { creating digital literacy and capacity-building projects, developing applications and content that } \\
\text { reflect multiculturality and identity, and addressing disability issues. }\end{array}$ \\
\hline
\end{tabular}

Source: Prepared by the authors, on the basis of information contained in national plans and agendas.

Many of these digital strategies exist under the framework of laws that explicitly recognize the rights of older adults to information and communication technologies, and in particular, the Internet (table 7). However, it is clear that the existence of these laws is a necessary but not sufficient condition to guarantee the right of older adults to ICT.

Table 7

Latin America (selected countries): national laws that recognize the rights of older adults to information and communication technologies

\begin{tabular}{|c|c|c|}
\hline Country & Law & Mention of older adults \\
\hline Argentina & Digital Argentina Act (2014) & $\begin{array}{l}\text { Service providers have an obligation to ensure that specific social groups, persons with } \\
\text { disabilities, among them users with serious vision impairment or visual disabilities, the hearing } \\
\text { impaired and speech impaired, older persons and users with special social needs have access } \\
\text { to services in conditions comparable to other users, pursuant to the provisions of the applicable } \\
\text { legislation (article 62, para. c). }\end{array}$ \\
\hline $\begin{array}{l}\text { Bolivia } \\
\text { (Plurinational } \\
\text { State of) }\end{array}$ & $\begin{array}{l}\text { General Law No. } 164 \text { of } 8 \text { April } \\
2011 \text { on telecommunications } \\
\text { and information and } \\
\text { communication technologies }\end{array}$ & $\begin{array}{l}\text { The service contract must guarantee that persons with disabilities have adequate access to } \\
\text { services (article 26, para. II (3)); users with disabilities and older adults have the right to be } \\
\text { provided with accessible telecommunications and information and communication technology, } \\
\text { as specified in the implementing regulations (article 54, para. 18); providers must facilitate } \\
\text { access to telecommunications and information and communication technology for users with } \\
\text { disabilities and older adults, as specified in the implementing regulations (article 59, para. 14). }\end{array}$ \\
\hline Brazil & Ordinance No. 16 (2012) & $\begin{array}{l}\text { Guarantee access to the network of ICT services to minority and marginalized groups, people } \\
\text { living in poverty, indigenous groups, persons with disabilities, the Afrodescendent population } \\
\text { and older adults. }\end{array}$ \\
\hline Colombia & $\begin{array}{l}\text { Law } 1221 \text { of } 2008 \text { establishing } \\
\text { the rules for the promotion and } \\
\text { regulation of teleworking and } \\
\text { other provisions }\end{array}$ & $\begin{array}{l}\text { The Ministry of Social Protection, within six (6) months of the enactment of this law, will } \\
\text { formulate a public policy to mainstream telework for vulnerable populations (persons with } \\
\text { disabilities, forcibly displaced populations, geographically isolated populations, female-headed } \\
\text { households, prisoners, and persons whose lives are threatened (article 3, para. 1). }\end{array}$ \\
\hline Costa Rica & $\begin{array}{l}\text { General Telecommunications } \\
\text { Law No. } 8642\end{array}$ & $\begin{array}{l}\text { Provide quality, timely and efficient telecommunications services at affordable and competitive } \\
\text { rates to institutions and to persons with special social needs, including shelters for children, } \\
\text { older persons, persons with disabilities, indigenous peoples, public schools, and public health } \\
\text { centres (article 32, para. (c)). }\end{array}$ \\
\hline
\end{tabular}

Source: Prepared by the authors. 
With regard to the outline of programmes promoting ICT use among older adults presented below, it is important to note, first, that the practices described are not exhaustive or representative of what is being done in the different countries of the region, neither can they be considered "best practices". They merely provide a snapshot of some of the programmes that are currently in existence in the region. Second, what follows should be taken as a preliminary approach since the lack of the necessary information made it impossible to examine key aspects of the programmes, such as coverage, performance, results, impact and financing, among others. - These, then, may be identified as priorities for future research.

Table 8 summarizes some of the basic characteristics of the digital inclusion programmes for the older adults that are being implemented in the region. Two points are worth highlighting in this regard. The first is that digital inclusion amongst older adults is promoted by providing access to digital technologies and, at the same time, by developing digital skills (particularly, those related to digital literacy) through computing workshops. In their most recent work, Van Deursen and Van Dijk (2014) argue that the concept of "access" is multifaceted and includes four different aspects: motivation to use computers and the Internet ('motivational access'); physical access - be it private or public - to computers and the Internet, ('material access'); digital skills ('skills access'); and, usage opportunities ('usage access'). According to Van Dijk, access problems gradually shift from physical to the usage access (which, as mentioned in Section III, has been termed the 'second digital divide').

Table 8

Latin America (selected countries): examples of programmes for the digital inclusion of older adults

\begin{tabular}{|c|c|c|c|c|}
\hline Country & Initiative & $\begin{array}{l}\text { Implementation } \\
\text { period }\end{array}$ & Form & Implemented by \\
\hline \multirow[t]{2}{*}{ Argentina } & Postas Digitales programme & & Computing workshops & Buenos Aires City Government \\
\hline & $\begin{array}{l}\text { University for Older Adults } \\
\text { (UPAMI) programme }\end{array}$ & & $\begin{array}{l}\text { Digital and technology } \\
\text { literacy courses for } \\
\text { everyday life }\end{array}$ & $\begin{array}{l}\text { Universities offering courses for older } \\
\text { adults and the elder care programme }\end{array}$ \\
\hline \multirow[t]{3}{*}{ Costa Rica } & Courses in technology & & Basic computing courses & $\begin{array}{l}\text { The Costa Rican Gerontology Association } \\
\text { (AGECO) and Gerontological Training } \\
\text { Institute (IGEF) }\end{array}$ \\
\hline & Ciudadano de Oro programme & & Basic computing courses & $\begin{array}{l}\text { National Council for Older Persons } \\
\text { (CONAPAM), the Costa Rican Social } \\
\text { Security Fund and the Latin American } \\
\text { University for Science and Technology } \\
\text { (ULACIT) of Costa Rica }\end{array}$ \\
\hline & $\begin{array}{l}\text { ED-1498 project: Digital technologies } \\
\text { for older adults under the Tecnologías } \\
\text { Educativas Avanzadas } \\
\text { (PROTEA) programme }\end{array}$ & 2005 & Internet courses & University of Costa Rica \\
\hline Chile & Chile Mayor Digit@l 2.0 & 2013-present & $\begin{array}{l}\text { Installation of Digital } \\
\text { Citizen Plazas }\end{array}$ & $\begin{array}{l}\text { National Service for Older Adults of Chile } \\
\text { and the Rural Training Foundation } \\
\text { of the Catholic University of Chile }\end{array}$ \\
\hline \multirow[t]{2}{*}{ Mexico } & $\begin{array}{l}\text { Digital education courses by Universidad } \\
\text { Autónoma de Nueva León }\end{array}$ & In progress & Free computer courses & $\begin{array}{l}\text { University for Older Adults, as part of the } \\
\text { University of the Third Age network }\end{array}$ \\
\hline & Biblioteca digital TELMEX & In progress & Digital inclusion courses & $\begin{array}{l}\text { Teléfonos de México (TELMEX) } \\
\text { and the Carlos Slim Foundation }\end{array}$ \\
\hline Peru & $\begin{array}{l}\text { Campaña Gratuita de } \\
\text { Alfabetización Digital }\end{array}$ & 2013 & $\begin{array}{l}\text { Computer and } \\
\text { Internet courses }\end{array}$ & $\begin{array}{l}\text { Peruvian Association of } \\
\text { Professional Engineers }\end{array}$ \\
\hline Uruguay & Plan Ibirapitá & 2015 & $\begin{array}{l}\text { Provides electronic } \\
\text { tablets to retirees } \\
\text { and pensioners } \\
\text { and basic courses }\end{array}$ & Plan Ceibal \\
\hline
\end{tabular}

Source: Prepared by the authors.

The programmes considered offer "material access" for the digital inclusion of older adults in the region. This is the case, for instance, with the Postas Digitales programme implemented by the Government of the City of Buenos Aires which aims to bring older adults closer to digital technology by setting up 
public centres, equipped with computers and an Internet connection, in different neighbourhoods. These centres also serve as meeting places where older adults can socialize.

The Chile Mayor Digital 2.0 programme offers digital literacy training workshops, albeit in a somewhat broader sense than the examples above. The idea is to acquaint older adults with platforms that can help them in their daily lives, enabling them to maintain communication with loved ones, interact with older adult groups across the country through social networks and learning about web sites. The programme also provides courses and thematic seminars that aim to promote Internet use by raising awareness of the opportunities that digital networks offer, for example, local government web portals which give information on the different programmes, workshops, benefits and the like available to older persons or which allow them to carry out administrative tasks online.

It should be noted that such spaces offering "material access", particularly to the poor and the vulnerable, presuppose that older adults have the motivation to use computers and the Internet. However, these technological spaces are established with the aim of developing digital skills, particularly those related to digital literacy. In the strict sense, and following Van Dijk's model, "digital literacy" refers to digital skills which are medium-related, that is, operational skills (knowing the actions required to operate a digital medium) and formal skills (knowing how to handle the formal structures of the medium: browsing, searches). Some of the programmes in existence seek to go further and develop content-related skills. ${ }^{8}$

For example, under the Postas Digitales programme, digital literacy workshops are provided for older adults, twice a week for a period of six months. To complement the training received, participants are given a guidebook of medium-related skills, including both operational and formal skills. Thus, the programme seeks to contribute to the Government's commitment to integrate 100,000 older adults in the digital world.

Another example is the Alfabetización digital para el adulto mayor programme in Lima, which is designed for older adults with little or no knowledge of communication technologies. The aim of the programme - which is sponsored by the Peruvian Association of Professional Engineers and is in its initial stage - is to give older adults the opportunity to learn medium-related digital skills so that they can use digital technologies in their daily lives. At the end of the training, the participants are expected to be able to use web tools such as search engines, browsers, email services and personal websites or blogs.

A different method for the promotion of digital inclusion among older adults has been implemented in Uruguay through the Plan Ibirapitá programme, which the Government of Uruguay launched in 2015 to complement training courses in digital technologies given by different institutions. Within the framework of Plan Ceibal, the programme aims to contribute towards equal access to knowledge and the social inclusion of retired persons.

Under the programme, electronic tablets are provided to introduce older persons and retirees of low socioeconomic level to the digital world. After a pilot test carried out in mid-2015 to assess and make adjustments to the software, the mass delivery of the devices began, with the planned delivery of 100,000 tablets in 2016. The tablets, specifically designed to be intuitive and user-friendly (simple access, large text and icons), are provided during a workshop in which the beneficiaries learn how to operate the hardware and the software. For many of them, this is their first contact with an electronic device. The workshop not only familiarizes them with the main features of the devices, but also provides an opportunity to relate to their peers and overcome any possible technophobia. Device content is grouped into four categories: health, entertainment, administrative tasks and communication. According to Novaresse (2015), the health category should be one of the most useful to beneficiaries,

8 "The medium-related skills account for the technicalities of media use, apparent in the operational and formal skills, whereas the content-related skills account for the aspects that relate to the content provided by the media, apparent in the information, communication, content creation, and strategic skills. The distinction has a sequential and conditional nature. In other words, the skills come after and on top of each other. For example, performing content-related skills requires the command of medium-related skills". See Van Deursen and Van Dijk (2014, p. 7). 
as it includes the Caléndula app which allows them to manage medication intake through a calendar in which users can enter personalized medication routines. The Ibirapita web page also provides tutorials on the technology. ${ }^{9}$ Interestingly, the programme includes a campaign that aims to help the children and grandchildren of the beneficiaries to use and adopt the technology.

The second aspect worth highlighting with regard to digital inclusion programmes for older adults in the region is that they are being implemented through different institutional arrangements. For example, Chile Adulto Mayor Digital 2.0 is administered by the National Service for Older Adults (which is a public service) in collaboration with the Rural Training Foundation of the Catholic University of Chile. This public-private initiative complements the Government's digital agenda to reduce the digital gap in the country. In the Plazas Digitales Ciudadanas programme, various public organisms and private enterprises show the many actions that can be done through the Internet to improve the quality of life of older adults. The initiative also requires the coordination of the national and local governments. The Postas Digitales programme is implemented by the Government of the City of Buenos Aires in coordination with the Ministry of Social Development and the Undersecretariat for Older Adults. This is a public initiative that works in connection with civil society organizations, associations and institutions catering to older adults.

In Lima, the digital literacy programme for older adults is coordinated by the Peruvian Association of Professional Engineers in collaboration with the University of Sciences and Humanities (through its Faculty of Engineering), through agreements signed with local governments, as was the case in the northern district of Comas. In Costa Rica, the Ciudadano de Oro programme is a joint initiative of the Latin American University of Science and Technology (ULACIT) of Costa Rica, the National Council for Older Persons (CONAPAM) and the Costa Rican Social Security Fund. The programme seeks to create a culture of respect for persons aged 65 or older, in recognition of their life of effort and work, by offering various free benefits, discounts and preferential treatment to older adults in possession of the card that identifies them as "golden citizens". Included in these benefits are digital literacy courses which aim to enhance the social contact, independence and development of older adults.

In short, a number of institutional arrangements are being explored to implement digital skills programmes for the social inclusion of the elderly population. However, the countries of the region must make greater efforts to further promote the use of digital media among older adults. These efforts should, at least, consider the following elements:

1. Strengthen the coordination among the different public sector, private sector and civil society entities that organize programmes to promote ICT usage among older adults to ensure that the programmes are mutually reinforcing.

2. Promote intergeneration skills development, whereby the younger generations assist older adults in becoming familiar with digital tools that are of use to them.

3. Promote opportunities for peer-to-peer training, where older adults who are actively engaged in the digital society help to train older adults who have not yet embraced digital technologies (as is the case in the Plan Ibirapitá programme).

4. Develop apps or other technological tools that respond directly to older adults' needs have and that can foster their inclusion in society and raise awareness on these technologies among older adults.

5. Expand access to the Internet in the home or via mobile devices for older adults, particularly for those residing in rural areas, those belonging to indigenous groups and those of low socioeconomic status.

9 See [online] http://ibirapita.org.uy. 
6. Improve data on ICT usage at the individual level -as this analysis reveals, few countries in the region have data that can be used to measure ICT usage among older adults, which makes it difficult to identify patterns and monitor policies.

7. Ideally, qualitative data should also be used, as they could further understanding of the barriers and factors that promote ICT use among older adults in Latin America and the Caribbean and provide insight on the most relevant issues that condition the use of ICT by this population (low levels of literacy, non-accessible formats, cost, lack of familiarity, individual perceptions of ICT, among others).

8. Promote greater participation of older adults in ICT development so that these tools better meet their needs and promote participation in the drafting of plans and strategies to expand ICT access and use among older adults.

\section{Conclusions}

This analysis provides a regional overview of ICT usage among older adults, a subject heretofore not examined fully despite its relevance in ageing societies. This study provides valuable evidence to guide policy and programme design and specific policy recommendations to expand access to ICT for older adults in the region and thus promote their inclusion. Despite this important contribution, some limitations should be kept in mind. For example, in 2014, 14.9\% of users in Latin America utilized devices other than personal computers to access the Internet, opting instead for mobile telephones or tablets (ECLAC, 2016b). Owing to the sources of data used for this study, it has not been possible to explore this type of Internet use. The authors were also limited by the number of household surveys in the region that include ICT modules. Although common patterns between the countries have been identified, given the extremely heterogeneous nature of Latin America, it is important to consider the specificities of each country and bear in mind that the data presented here may not apply to all contexts. Lastly, the fact that the study considers mainly public sector (and some civil society) initiatives promoting ICT usage among older adults although the private sector is clearly a key player as well may constitute a methodological flaw.

Despite these limitations, this study represents an important contribution. First, the results confirm the existence of a marked digital age divide - not only between countries, but also within them. Although the use of the Internet has increased for persons aged 60 or over across all countries, their usage levels are still quite low when compared to the 15-29 and the 30-59 age groups. Another interesting finding pertains to the fact that while many older adults in the region live in households with access to the Internet, a large percentage of them do not use it. This suggests that access is not the sole determinant in the use of ICT among older adults, but that motivation and skills, in other words the desire and the capacity to take advantage of these tools, are also necessary. For older adults, a lack of awareness of how these tools can address everyday needs may be an important barrier to ICT use. It is therefore important to raise awareness about the potential benefits of using ICT and develop ICT skills among older adults and those close to them.

The findings of this research also corroborate previous studies showing that in Latin America, household access to ICT is determined by the availability of infrastructure and other economic, social and demographic variables, such as housing location (ECLAC, 2016).

Certain social groups are also being excluded from the digital revolution that is under way in the region. As this analysis demonstrates, older adults belonging to indigenous groups are less likely to use the Internet than non-indigenous older adults, all else being equal. It must therefore be borne in mind that although ICT can help to reduce social inequalities, the current uneven access to these technologies may exacerbate these inequalities, as some reap the benefits while others remain behind. 
With the adoption of the 2030 Agenda for Sustainable Development, all countries in Latin America and the Caribbean pledged to leave no one behind. This means, among other things, taking decisive steps to reduce the persistent disparities that plague the region. The digital divide between generations and within the older adult population alike is a cause for concern because it could serve to widen gaps which must instead be reduced.

\section{Bibliography}

Abusleme, M. T. and others (2014), Inclusión y exclusión social de las personas mayores en Chile, Santiago, National Service for Older Adults/Faculty of Social Sciences at the University of Chile/Latin American Faculty of Social Sciences (FLACSO)-Chile.

Andreasson, K. (ed.) (2015), Digital Divides: the New Challenges and Opportunities of e-Inclusion, Boca Raton, CRC Press.

Balboni, M., S. Rovira and S. Vergara (eds.) (2011), ICT in Latin America: A Microdata Analysis (LC/R.2172), Santiago, Economic Commission for Latin America and the Caribbean (ECLAC).

Boonaert, T. and N. Vettenberg (2011), "Young people's internet use: divided or diversified?", Childhood, vol. 18, No. 1, SAGE.

Camacho, K. (2004), "Retos para evaluar el impacto de la internet: el caso de las organizaciones de la sociedad civil centroamericana", Acceso Foundation [online] https://revistas.um.es/analesdoc/article/ view/1721/1771.

Castaño, C. (2008), "La primera y la segunda brecha digital”, La segunda brecha digital, C. Castaño (coord.), Madrid, Cátedra.

ECLAC (Economic Commission for Latin America and the Caribbean) (2016a), The Social Inequality Matrix in Latin America (LC/G.2690(MDS.1/2)), Santiago.

(2016b), The New Digital Revolution: From the Consumer Internet to the Industrial Internet (LC/L.4029/Rev.1), Santiago.

(2012), San José Charter on the Rights of Older Persons in Latin America and the Caribbean (LC/G.2537), Santiago [online] http://repositorio.cepal.org/bitstream/handle/11362/21535/S2012897_ en.pdf?sequence $=1$ \&isAllowed $=y$.

(2007), Report on the Application of the Regional Strategy for the Implementation in Latin America and the Caribbean of the Madrid International Plan of Action on Ageing (LC/L.2749(CRE-2/3)), Santiago.

Elwick, A. and others (2013), Beyond the Digital Divide: Young People and ICT, CfBT Education Trust [online] https://www.educationdevelopmenttrust.com/ /media/EDT/Reports/Research/2013/r-beyond-the-digitaldivide-perspective-2013.pdf.

Gutiérrez, L. H. and L. E. Gamboa (2010), "Determinants of ICT usage among low-income groups in Colombia, Mexico, and Peru", The Information Society, vol. 26, No. 5, Taylor \& Francis.

Huenchuan, S. (2013), "Perspectivas globales sobre la protección de los derechos humanos de las personas mayores, 2007-2013", Project Documents (LCM.566), Santiago, Economic Commission for Latin America and the Caribbean (ECLAC).

Novaresse, C. (2015), "Así funcionan las tabletas para jubilados" [online] https://www.cromo.com.uy/asifuncionan-las-tabletas-jubilados-n654160.

OAS (Organization of American States) (2015), "The Inter-American Convention on Protecting the Human Rights of Older Persons" [online] http://www.oas.org/en/sla/dil/inter_american_treaties_a-70_human_ rights_older_persons.asp.

Piscitelli, A. (2009), Nativos digitales: dieta cognitiva, inteligencia colectiva y arquitecturas de la participación, Buenos Aires, Santillana.

Prensky, M. (2001), "Digital natives, digital immigrants", On the Horizon, vol. 9, No. 5 [online] http:// www.marcprensky.com/writing/Prensky\%20-\%20Digital\%20Natives,\%20Digital\%2Olmmigrants\%20 -\%20Part1.pdf.

Selwyn, N. (2004), "Reconsidering political and popular understandings of the digital divide", New Media Society, vol. 6, No. 3, SAGE.

(2003), "Apart from technology: understanding people's non-use of information and communication technologies in everyday life", Technology in Society, vol. 25, No. 1, Amsterdam, Elsevier. 
Selwyn, N. and K. Facer (2007), Beyond the Digital Divide: Rethinking Digital Inclusion for the 21st Century, Futurelab [online] https://www.nfer.ac.uk/publications/FUTL55.

United Nations (2015), World Population Prospects. The 2015 Revision (ESA/P/WP.241), New York.

_ (2002), Political Declaration and Madrid International Plan of Action on Ageing, New York [online] http:// www.un.org/en/events/pastevents/pdfs/Madrid_plan.pdf.

Van Deursen, A. and J. van Dijk (2014), Digital Skills: Unlocking the Information Society, Basingstoke, Palgrave Macmillan.

WHO (World Health Organization) (2002), Active Ageing: A Policy Framework [online] http://www.who.int/ ageing/publications/active_ageing/en/.

WSIS (World Summit on the Information Society) (2016), "WSIS background" [online] https://www.itu.int/ net4/wsis/forum/2016/About/Background. 


\section{Annex A1}

Table A1.1

Latin America (selected countries): characteristics of older adults who use ICT (Percentages and years)

\begin{tabular}{|c|c|c|c|c|c|c|c|c|c|}
\hline & \multirow{2}{*}{$\begin{array}{c}\text { Mean age } \\
\text { (years) }\end{array}$} & \multirow{2}{*}{$\begin{array}{c}\text { Male } \\
\text { (percentage) }\end{array}$} & \multirow{2}{*}{$\begin{array}{c}\text { Urban } \\
\text { (percentage) }\end{array}$} & \multirow{2}{*}{$\begin{array}{l}\text { Mean } \\
\text { education } \\
\text { (years) }\end{array}$} & \multirow{2}{*}{$\begin{array}{l}\text { Indigenous } \\
\text { ethnicity } \\
\text { (percentage) }\end{array}$} & \multicolumn{4}{|c|}{$\begin{array}{l}\text { Marital status } \\
\text { (percentages) }\end{array}$} \\
\hline & & & & & & Married & Single & Widowed & Divorced \\
\hline Chile & 70.8 & 42.7 & 85.3 & 8.2 & 6.0 & 56.9 & 22.7 & 2.0 & 6.7 \\
\hline Ecuador & 70.5 & 47.6 & 65.3 & 5.9 & 14.6 & 58.2 & 7.3 & 22.6 & 12.0 \\
\hline El Salvador & 71.1 & 45.0 & 65.5 & 4.1 & & 50.2 & 7.3 & 26.7 & 15.8 \\
\hline Honduras & 70.2 & 46.1 & 56.9 & 4.7 & & 56.4 & 19.2 & 18.6 & 5.9 \\
\hline Mexico & 70.3 & 46.1 & & & & & & & \\
\hline Paraguay & 69.8 & 48.4 & 59.5 & 5.7 & & 59.5 & 11.6 & 22.5 & 6.4 \\
\hline Peru & 70.8 & 46.7 & 75.2 & 6.2 & 49.1 & 60.9 & 5.3 & 23.8 & 10.1 \\
\hline Uruguay & 71.6 & 42.0 & 94.3 & 7.7 & 7.1 & 56.3 & 4.7 & 24.9 & 10.8 \\
\hline
\end{tabular}

Source: Prepared by the authors, on the basis of the National Socioeconomic Survey (CASEN) of Chile, 2015; the National Survey of Employment, Unemployment and Underemployment in urban and rural areas of Ecuador, 2015; the Multi-purpose Household Survey of El Salvador, 2015; the Permanent Multi-purpose Household Survey of Honduras, 2015; the Module on Availability and Use of Information Technologies in Households (MODUTIH) of Mexico, 2014; the Permanent Household Survey of Paraguay, 2015; the National Household Survey on Life Conditions and Poverty of Peru, 2015; and the Continuous Household Survey of Uruguay, 2015. 